\title{
Efek Analgetik Ekstrak Etanol Kelopak Rosella (Hibiscus sabdariffa L) Pada Mencit Jantan (Mus musculus)
}

\author{
Ridwan Baihaqi ${ }^{1}$, M. Yulis Hamidy ${ }^{2}$, Eka Bebasari ${ }^{3^{*}}$
}

\begin{abstract}
Indonesia has been known for its traditional medicine and one of the plants used for tradisional medicine is Hibiscus sabdariffa L. The roselle (Hibiscus sabdariffa L) calyx has antipyretic effect by blocking prostaglandin synthesis. The purpose of this study was to find out the existences of analgesic effect of roselle (Hibiscus sabdariffa L) calyx ethanol extract. This experimental research used a post test only design that was conducted on 25 male mices weighting 20$35 \mathrm{~g}$. The mices were divided into 5 treatment groups and given the CMC-Na 0,5\% (negative control), asetosal $65 \mathrm{mg} /$ $\mathrm{kgBB}$ (positive control) and groups of roselle (Hibiscus sabdariffa L) calyx ethanol extract dose of $200 \mathrm{mg} / \mathrm{kgBB}$, $400 \mathrm{mg} / \mathrm{kgBB}$ and $800 \mathrm{mg} / \mathrm{kgBB}$. Pain stimulus was given chemically by using $1 \%$ acetic acid that injected intraperitoneally 30 minutes after sample was given the extract, the response of the mices will be writhing. It called positive response if percentage potency of analgesic e" $50 \%$. The result of this research showed that all dosage of roselle (Hibiscus sabdariffa L) calyx ethanol extract had an analgesic effect.
\end{abstract}

Keywords: analgesic, roselle (Hibiscus sabdariffa L) calyx, asetosal, writhing, mice

Nyeri merupakan keluhan paling umum yang membawa pasien menemui dokter. ${ }^{1}$ Menurut International Association for the Study of Pain menyatakan bahwa nyeri adalah pengalaman sensorik dan emosional yang tidak menyenangkan sehubungan dengan kerusakan jaringan, baik aktual maupun potensial, atau yang digambarkan dalam bentuk kerusakan tersebut. ${ }^{2}$ Rasa nyeri merupakan salah satu bentuk manifestasi dari adanya suatu penyakit. ${ }^{3}$ Fungsi sistem sensorik nyeri adalah untuk mendeteksi, melokalisasi dan mengidentifikasi proses kerusakan jaringan. Penyakit yang berbeda menimbulkan pola khas kerusakan jaringan, kualitas, lama dan lokasi keluhan nyeri. Lokasi nyeri pada pemeriksaan dapat memberikan petunjuk diagnostik penting dan digunakan untuk mengevaluasi respons terhadap pengobatan. ${ }^{1}$

Menurut penelitian di Amerika Serikat pada tahun 2004 mengatakan bahwa nyeri merupakan keluhan yang umum dialami pasien setelah

\footnotetext{
${ }^{1}$ Mahasiswa Fakuktas Kedokteran Universitas Riau

${ }^{2}$ Bagian Farmakologi Fakultas Kedokteran Universitas Riau

3* Coresponding Author:Bagian Fisiologi Fakultas Kedokteran Universitas Riau
}

menjalani operasi. Sebanyak $80 \%$ pasien mengalami rasa nyeri pasca operasi dimana $11-20 \%$ pasien mengalami nyeri hebat. Penelitian ini mengatakan bahwa saat pasien memiliki nyeri sedang sampai berat, mereka hanya memiliki 50\% kesempatan untuk memperoleh pengobatan analgetik yang adekuat. ${ }^{4}$ Permasalahan timbul bila nyeri yang dihadapi penderita bersifat menahun dengan sebab yang kurang jelas, sehingga banyak upaya dilakukan untuk meringankan rasa nyeri, salah satunya adalah dengan penggunaan obat analgetik. ${ }^{3}$

Analgetik merupakan suatu senyawa atau obat yang digunakan untuk mengurangi rasa sakit atau nyeri yang diakibatkan oleh berbagai rangsangan pada tubuh baik rangsangan mekanis, kimiawi dan fisika. ${ }^{5}$ Rasa nyeri yang disebabkan oleh rangsangan-rangsangan mekanis, kimiawi dan fisika dapat menimbulkan kerusakan pada jaringan yang memicu pelepasan mediator nyeri seperti bradikinin dan prostaglandin yang akhirnya mengaktivasi reseptor nyeri di saraf perifer dan diteruskan ke otak. $^{5}$

Sumber pengobatan di dunia mencakup tiga sektor yang saling terkait, yaitu pengobatan rumah 
tangga atau pengobatan sendiri, pengobatan medis dan pengobatan tradisional. ${ }^{6}$ Akhir-akhir ini gerakan kembali ke alam semakin gencar dilakukan oleh masyarakat tanpa terkecuali masyarakat Indonesia. Gerakan kembali ke alam ditunjukkan oleh adanya keingintahuan untuk menggunakan dan mengkonsumsi produk-produk alamiah. ${ }^{7}$ World Health Organization (WHO) juga mendukung upaya-upaya dalam peningkatan keamanan dan khasiat dari obat tradisional. ${ }^{8}$

Salah satu tanaman yang memiliki khasiat sebagai obat tradisional adalah rosella (Hibiscus sabdariffa $\mathrm{L}$ ) yang memiliki nama daerah antara lain merambos ijo di daerah Jawa Tengah, kesew jawe di daerah Sumatera Selatan dan asam jarot di daerah Padang. ${ }^{9}$ Tumbuhan ini biasa digunakan sebagai obat antihipertensi, antikanker dan antidiabetes. Tumbuhan ini juga memiliki khasiat sebagai antikejang, antibakteri, mengobati cacingan dengan memperlambat pertumbuhan jamur, bakteri dan parasit penyebab demam tinggi. ${ }^{10}$ Kandungan penting yang terdapat pada kelopak rosella adalah pigmen antosianin yang membentuk flavonoid. Pada kelopak rosella juga mengandung kalsium, magnesium, fosfor, zat besi, asam amnio essensial dan omega-3. ${ }^{10}$ Senyawa flavonoid dapat menghambat enzim siklooksigenase yang dapat menurunkan sintesis prostaglandin.5 Prostaglandin merupakan mediator kimia yang disintesis melalui jalur siklooksigenase dan berperan pada berbagai proses nyeri. ${ }^{11}$ Menurut penelitian sebelumnya Hibiscus sabdariffa L mempunyai aktivitas antipiretik dengan cara menghambat prostaglandin pada dosis $400 \mathrm{mg} / \mathrm{kgBB}$ dan $800 \mathrm{mg} / \mathrm{kgBB} .{ }^{11}$ Berdasarkan uraian di atas, peneliti tertarik untuk melakukan penelitian terhadap ekstrak etanol kelopak rosella (Hibiscus sabdariffa L), dalam hal ini adalah untuk mengetahui efek analgetiknya dengan menggunakan metode induksi kimia.

\section{METODE}

\section{Bahan Tanaman dan Pembuatan Ekstrak}

Bahan yang digunakan dalam penelitian ini adalah kelopak rosella yang berasal dari perkebunan di daerah Pandau Permai, Kampar sebanyak $2 \mathrm{~kg}$ berumur 4-5 bulan. Ekstraksi dilakukan secara maserasi menggunakan etanol 96\%. Seluruh maserat dikentalkan dengan rotary evaporator sehingga didapat ekstrak kental.

\section{Penentuan Dosis Asetosal}

Penentuan dosis obat Asetosal menggunakan tabel konversi dosis berdasarkan perbandingan luas permukaan tubuh hewan. Dosis yang digunakan pada mencit adalah $65 \mathrm{mg} / \mathrm{kgBB} .{ }^{12}$

\section{Hewan coba}

Hewan coba yang digunakan pada penelitian ini adalah mencit jantan (Mus musculus). Mencit dipelihara di rumah mencit di Fakultas Kedokteran Universitas Riau. Mencit dipelihara pada kandang yang bersih, suhu ruangan dan ventilasi udara yang baik serta akses bebas untuk mendapatkan makanan dan minuman.

Mencit yang digunakan berjumlah 25 ekor dengan berat 20-30 g dibagi dalam 5 kelompok hewan coba (I,II,III,IV,V). Kelompok I diberi CMC$\mathrm{Na} \mathrm{0,5 \%} \mathrm{0,2} \mathrm{ml/20} \mathrm{gBB,} \mathrm{kelompok} \mathrm{II} \mathrm{diberi} \mathrm{asetosal}$ $65 \mathrm{mg} / \mathrm{KgBB}$, kelompok III diberi ekstrak etanol kelopak rosella $200 \mathrm{mg} / \mathrm{kgBB}$, kelompok IV diberi ekstrak etanol kelopak rosella $400 \mathrm{mg} / \mathrm{kgBB}$ dan kelompok $\mathrm{V}$ diberi ekstrak etanol kelopak rosella $800 \mathrm{mg} / \mathrm{kgBB}$.

\section{Uji Efek Analgetik}

Pada penelitian ini digunakan ekstrak etanol kelopak rosella sebagai bahan uji. Efek analgetik ekstrak etanol kelopak rosella diuji dengan menggunakan metode induksi kimiawi menggunakan asam asetat $1 \%$. Mencit dipuasakan selama 18 jam sebelum pengujian, namun tetap diberikan minum. Mencit dibagi menjadi 5 kelompok secara acak dengan 5 ekor setiap kelompok. Untuk masing-masing kelompok diberikan bahan uji peroral sebanyak satu kali. Setelah 30 menit pemberian bahan uji, mencit diberi rangsangan kimia berupa asam asetat $1 \%$ secara intraperitoneal. Setiap 5 menit selama 30 menit dicatat jumlah geliat yang ditunjukkan oleh mencit. Geliat mencit ditandai dengan penarikan kedua kaki ke belakang serta menempelkan perut ke lantai. selanjutnya dihitung jumlah kumulatif geliat mencit 
dari masing-masing kelompok. Persentase daya analgetik dihitung dengan rumus: ${ }^{13}$

$$
\% \text { daya analgetik }=100-\left(-\frac{\mathrm{p}}{\mathrm{K}} \times 100 \%\right)
$$

Keterangan :

$\mathrm{P}=$ Rata-rata jumlah geliat mencit kelompok perlakuan

$\mathrm{K}=$ Rata-rata jumlah geliat mencit kelompok kontrol negative

\section{Analisis Data}

Seluruh data yang diperoleh kemudian dianalisis dengan menggunakan analisis varians (Anova). Dari sebaran data didapatkan data normal, lalu dilanjutkan dengan uji varians data, didapatkan varians data sama. Pengujian dilanjutkan dengan Anova untuk mengetahui kebermaknaan perbedaan data hasil penelitian, dari pengujian didapatkan $\mathrm{p}>0,05$, ini menunjukkan tidak terdapat perbedaan yang bermakna dari data hasil penelitian. Maka untuk pengujian LSD tidak dapat dilanjutkan.

\section{HASIL}

Pada tabel 1 terlihat jumlah kumulatif geliat mencit pada setiap kelompok perlakuan setelah diinduksi asam asetat $0,5 \%$. Jumlah geliat mencit lebih besar terdapat pada kelompok mencit yang diberi ekstrak etanol kelopak rosella dengan dosis $200 \mathrm{mg} / \mathrm{kgBB}$ daripada kelompok mencit yang diberikan dosis ekstrak etanol kelopak rosella lainnya. Jumlah geliat mencit lebih kecil terdapat pada kelompok mencit yang diberi dosis ekstrak etanol kelopak rosella $400 \mathrm{mg} / \mathrm{kgBB}$.

Tabel 1. Jumlah kumulatif geliat mencit pada setiap kelompok perlakuan setelah diinduksi asam asetat $0,5 \%$.

\begin{tabular}{|c|c|c|c|c|c|c|c|}
\hline \multirow[t]{2}{*}{$\begin{array}{l}\text { Kelompok } \\
\text { perlakuan }\end{array}$} & \multicolumn{5}{|c|}{$\begin{array}{l}\text { Jumlah kumulatif geliat mencit } \\
\text { setiap } 5 \text { menit selama } 30 \text { menit }\end{array}$} & \multirow[t]{2}{*}{ Total } & \multirow[t]{2}{*}{ Rerata } \\
\hline & 1 & 2 & 3 & 4 & 5 & & \\
\hline I & 61 & 102 & 147 & 52 & 112 & 471 & 91,8 \\
\hline II & 15 & 50 & 53 & 10 & 11 & 232 & 16,1 \\
\hline III & 23 & 51 & 29 & 79 & 40 & 222 & 44,4 \\
\hline IV & 46 & 58 & 17 & 43 & 51 & 215 & 43 \\
\hline $\mathrm{V}$ & 26 & 10 & 21 & 52 & 26 & 168 & 33.6 \\
\hline
\end{tabular}

Hasil pada tabel 2 menunjukkan persentase daya analgetik pada setiap kelompok perlakuan. Persentase tertinggi terdapat pada kelompok yang diberi dosis ekstrak etanol kelopak rosella $400 \mathrm{mg} /$ $\mathrm{kgBB}$ dan yang terkecil terdapat pada kelompok yang diberi dosis ekstrak etanol kelopak rosella 200 $\mathrm{mg} / \mathrm{kgBB}$.

Tabel 2. Persentase daya analgetik pada kelompok perlakuan ekstrak etanol kelopak rosella dosis $200 \mathrm{mg} /$ $\mathrm{kgBB}, 400 \mathrm{mg} / \mathrm{kgBB}, 800 \mathrm{mg} / \mathrm{kgBB}$ dan kontrol positif terhadap kontrol negatif.

\begin{tabular}{cccccccc}
\hline $\begin{array}{c}\text { Kelompok } \\
\text { perlakuan }\end{array}$ & \multicolumn{9}{c}{ Persen daya analgetik mencil } & $\begin{array}{c}\text { Rerala } \\
(\%)\end{array}$ \\
\cline { 2 - 6 } & $\mathbf{1}$ & $\mathbf{2}$ & $\mathbf{3}$ & $\mathbf{4}$ & $\mathbf{5}$ & \\
\cline { 1 - 5 } II & 52,54 & 47,26 & 44,1 & 57,81 & 53,59 & 51,06 \\
III & 75,74 & 46,21 & 69,41 & 16,67 & 50,81 & 51,76 \\
IV & 51,48 & $\mathbf{3 8 , 8 2}$ & 82,07 & 54,65 & 46,21 & 54,64 \\
V & 72,58 & 57,81 & 74,69 & 45,15 & 72,58 & 64,56 \\
\hline
\end{tabular}




\section{PEMBAHASAN}

\section{Efek analgetik ekstrak etanol kelopak rosella}

Hasil penelitian yang dilakukan di laboratorium Farmakologi Fakultas Kedokteran Universitas Riau menunjukkan bahwa ekstrak etanol kelopak rosella (Hibiscus sabdariffa L) memiliki efek analgetik yang dibuktikan dengan penurunan geliat mencit setelah diinduksi asam asetat sebagai perangsang rasa nyeri. Hal ini dapat disimpulkan karena pada metode kimia penurunan geliat mencit dapat dijadikan ukuran dalam mengevaluasi aktivitas analgetik. Respon analgetik dinyatakan positif jika didapatkan persentase daya analgetik e" $50 \% .^{13}$

Induksi rasa nyeri secara kimiawi digunakan asam asetat $1 \%$ dengan cara disuntikkan secara intraperitoneal yang diberikan 30 menit setelah pemberian bahan uji secara oral.12 Nyeri ditandai dengan timbulnya writhing atau geliat yang ditunjukkan dengan bagian abdomen menyentuh dasar tempat berpijak dan kedua pasang kaki ditarik ke belakang. ${ }^{14}$

Dari tabel jumlah kumulatif geliat mencit terlihat bahwa jumlah geliat yang terbentuk pada kelompok kontrol negatif meningkat pada mencit kedua, ketiga dan kelima sebesar 102, 147 dan 112, namun pada mencit kesatu dan keempat jumlah geliat mencit mengalami penurunan sebesar 61 dan 52. Hal ini diduga adanya mekanisme alami tubuh dalam melawan efek nyeri. Tubuh dalam hal ini jaringan intraperitoneal yang disuntikkan asam asetat $1 \%$ sangat mungkin mengadakan perbaikan karena proses nyeri ini tidak menimbulkan kerusakan jaringan dan berlangsung singkat serta adanya respon imun tubuh dalam melawan mediator pencetus rasa nyeri. ${ }^{15}$

Pada kelompok ekstrak etanol kelopak rosella pada dosis $200 \mathrm{mg} / \mathrm{kgBB}$ jumlah geliat mencit lebih besar daripada kelompok mencit yang diberikan dosis ekstrak etanol kelopak rosella lainnya yaitu sebesar 79 pada mencit keempat. Pada dosis 400 $\mathrm{mg} / \mathrm{kgBB}$ jumlah geliat mencit lebih kecil dari dosis ekstrak etanol kelopak rosella lainnya yaitu sebesar 17 pada mencit ketiga. Efek yang tidak nyata pada kelompok dosis tersebut dapat disebabkan oleh beberapa faktor, yaitu faktor pengamatan dan faktorfaktor yang mempengaruhi respons tubuh terhadap ekstrak yang diberikan. Kesalahan pada pengamatan terjadi pada saat melihat jumlah geliat yang terjadi pada mencit, hal ini karena dilakukan oleh orang yang berbeda. Respons tubuh terhadap ekstrak yang diberikan dapat bervariasi pada setiap hewan coba. Respons tersebut dapat disebabkan oleh perbedaan genetik dalam metabolisme esktrak dan bioavailabilitas ekstrak. ${ }^{16}$

Pada penelitian ini terlihat bahwa seluruh kelompok percobaan yang diberi ekstrak etanol kelopak rosella menunjukkan jumlah kumulatif geliat mencit lebih kecil dibandingkan dengan kelompok kontrol negatif. Kemampuan ekstrak dalam mengurangi jumlah geliat menunjukkan bahwa ekstrak etanol kelopak rosella memiliki efek analgetik pada dosis $200 \mathrm{mg} / \mathrm{kgBB}, 400 \mathrm{mg} / \mathrm{kgBB}$ dan $800 \mathrm{mg} / \mathrm{kgBB}$.

Hasil pada tabel 2 menunjukkan bahwa setiap kelompok ekstrak etanol kelopak rosella menunjukkan persentase daya analgetik yang berbeda-beda pada setiap kelompok perlakuan. Persentasetase rata-rata masing-masing kelompok perlakuan ekstrak semakin meningkat dengan bertambahnya dosis ekstrak etanol kelopak rosella yang diberikan. Persentase daya analgetik rerata semakin meningkat mulai dosis $200 \mathrm{mg} / \mathrm{kgBB}, 400$ $\mathrm{mg} / \mathrm{kgBB}$ dan $800 \mathrm{mg} / \mathrm{kgBB}$. Ini menunjukkan bahwa pada setiap dosis ekstrak etanol kelopak rosella $200 \mathrm{mg} / \mathrm{kgBB}, 400 \mathrm{mg} / \mathrm{kgBB}$ dan $800 \mathrm{mg} /$ $\mathrm{kgBB}$ positif sebagai analgetik karena persentase daya analgetiknya e"50\%.

Hasil penelitian juga menunjukkan bahwa persentase daya analgetik rerata terbesar diantara kelompok yang mendapatkan perlakuan ekstrak etanol kelopak rosella dihasilkan oleh dosis $800 \mathrm{mg} /$ $\mathrm{kgBB}$ sebesar $64,56 \%$. Berdasarkan persentase daya analgetik tersebut, ekstrak etanol kelopak rosella diduga memiliki kemampuan dalam menghambat pelepasan dari histamin, serotonin, bradikinin dan pembentukan prostaglandin. 15 Hasil penelitian ini sesuai dengan penelitian yang dilakukan oleh Wantana Reanmongkol, bahwa ekstrak etanol kelopak rosella diduga memiliki mekanisme kerja menghambat biosintesis prostaglandin. ${ }^{11}$

Analisis fitokimia dari kelopak rosella menunjukkan adanya flavonoid dan fenol. Senyawa flavonoid merupakan salah satu komponen utama rosella yang dapat menghambat enzim 
siklooksigenase yang dapat menurunkan sintesis prostaglandin.5 Senyawa ini diduga berperan dalam menghambat efek analgetik pada penelitian ini. Hal ini berdasarkan pada beberapa penelitian sebelumnya yang telah membuktikan bahwa senyawa kimia tersebut memiliki efek analgetik. ${ }^{11}$

Pada setiap kelompok ekstrak etanol kelopak rosella dosis $200 \mathrm{mg} / \mathrm{kgBB}$, dosis $400 \mathrm{mg} / \mathrm{kgBB}$ dan dosis $800 \mathrm{mg} / \mathrm{kgBB}$ tidak terdapat perbedaan signifikan antar sesama kelompok ekstrak etanol kelopak rosella karena hasil uji Anova didapatkan hasil $p>0,05$. Hal ini menunjukkan bahwa ekstrak etanol kelopak rosella pada semua dosis hampir sama efek analgetik pada setiap kelompok secara statistik.

\section{Perbandingan efek analgetik ekstrak etanol kelopak rosella terhadap asetosal}

Pada penelitian ini didapatkan hasil bahwa asetosal menunjukkan jumlah kumulatif geliat mencit lebih kecil dibandingkan dengan kontrol negatif dan didapatkan persentase daya analgetik rerata sebesar $51,06 \%$. Ini menunjukkan asetosal memiliki efek analgetik dengan kerja menghambat enzim siklooksigenase $(C O X)$ sehingga konversi asam arakhidonat terganggu. ${ }^{17}$ Pada hasil penelitian didapatkan bahwa persentase daya analgetik pada kelompok asetosal dan ekstrak etanol kelopak rosella sama-sama menunjukkan adanya efek analgetik dengan persentase daya analgetik $>50 \%$. Hal ini menunjukkan bahwa asetosal dan semua dosis ekstrak kelopak rosella memiliki efek analgetik yang sama dalam mengurangi geliat mencit.

Penelitian ini juga memperlihatkan efek analgetik asetosal yang dibandingkan dengan ekstrak etanol kelopak rosella, dimana efek analgetik ekstrak etanol kelopak rosella dosis $200 \mathrm{mg} / \mathrm{kgBB}$ lebih besar daripada dosis asetosal. Namun secara statistik efek analgetik asetosal dengan semua dosis ekstrak etanol kelopak rosella tidak terdapat perbedaan yang bermakna. Hal ini menunjukkan bahwa asetosal dan semua dosis ekstrak kelopak rosella memiliki efek analgetik yang sama dalam mengurangi geliat mencit.

\section{SIMPULAN}

\section{Simpulan}

Penelitian ekstrak etanol kelopak rosella (Hibiscus sabdariffa $\mathrm{L}$ ) dosis $200 \mathrm{mg} / \mathrm{kgBB}, 400$ $\mathrm{mg} / \mathrm{kgBB}$ dan $800 \mathrm{mg} / \mathrm{kgBB}$ menunjukkan adanya efek analgetik dengan menggunakan metode induksi kimia. Namun tidak ditemukan perbedaan yang bermakna secara statistik efek analgetik antara dosis $200 \mathrm{mg} / \mathrm{kgBB}$, dosis $400 \mathrm{mg} / \mathrm{kgBB}$ dan dosis $800 \mathrm{mg} /$ $\mathrm{kgBB}$.

\section{Saran}

Dilakukan penelitian lanjutan tentang efek samping yang mungkin timbul pada penggunaan ekstrak etanol kelopak rosella (Hibsicus sabdariffa L) sebagai analgetik, baik secara invitro maupun invivo. Serta dilakukan isolasi terhadap kandungan kelopak rosella agar dapat diketahui zat aktif yang lebih spesifik pada kelopak rosella yang dapat menghasilkan efek sebagai analgetik.

\section{UCAPAN TERIMA KASIH}

Penulis mengucapkan terima kasih kepada semua pihak yang membantu dalam menyelesaikan penelitian ini.

\section{DAFTAR PUSTAKA}

1. Howard FL, Joseph BM. Pain: pathophysiology and management. Horrison' Principles of Internal Medicine- 16 th Ed. Part two- Cardinal Manifestation and presentation of disease. New York: McGraw-Hill Profesional. 2005.

2. International Association for the Study of Pain. Pain defenitions.http://www.iasp-pain.org/AM/ Template.cfm?Section=Pain_Definitions\&Template=/ CM/HTMLDisplay.cfm\&ContentID $=1728$ (diakses tanggal 26 Desember 2010.10:19)

3. Potter, Perry. Fundamental Keperawatan. Vol: 2. Jakarta : EGC : 2006

4. Nancy W, Chris P, Margo M. Improving the Quality of Care Through Pain Assessment and Management. http://www.ncbi.nlm.nih.gov/ pubmed/21328759 (diakses tanggal 08 Maret 2011) 
5. Handoko TSK. Anastetik umum. Farmakologi dan terapi. Edisi 5. Gaya Baru, Jakarta:2005.

6. Sudibyo S, Sarjaini J, Agnes ML. Beberapa faktor yang berhubungan dengan penggunaan obat tradisional dalam pengobatan sendiri di Indonesia. Litbangkes Depkes RI. 2003.

7. Supriyadi, dkk. Tumbuhan Obat Indonesia: Penggunaan dan Khasiatnya. Jakarta: 2001

8. WHO, Tradisional medicine, $2003 \mathrm{http}: / /$ www.who.int/mediacentre/factsheets/fs134/en/, (diakses tanggal 24 desember 2010)

9. Idawanni. Rosella Bunga Cantik Berkhasiat Obat. http://www.litbang.deptan.go.id (diakses tanggal 29 Maret 2011)

10.Mardiah, Sawarni, Ashadi WR, Rahayu A. Budi Daya dan Pengolahan Rosela, Edisi 2. Jakarta: Agromedia Pustaka: 2009. Halaman 9-10

11. Reanmongkol W, Itharat A. Antipyretic activity of the extracts of Hibiscus sabdariffa calyces L. in experimental animals. Songklanakarin J. Sci. Technol. March 2007.

12.Turner RA. Screening methods in pharmacology. New York: Academic Press.1965.
13. Handershot LC, Forsaith J. Antagonism of the frequency of phenylquinone-induced writhing in the mouse by weak analgesics and non analgesics. J. 1959. Pharmacol. Exp. Ther.,125: 237-240.

14.Astuti N, Pudjiastuti. Penelitian khasiat biji ketumbar (Coriandrum sativum L.) sebagai analgesic pada mencit. Prosiding Simposium Penelitian Bahan Obat Alami VIII. Bogor: Badan Penelitian Tanaman Rempah dan Obat (BALITTRO) dengan Perhimpunan Peneliti Bahan Obat Alami (PERHIPBA). 1996.

15.Guyton AC. Fisiologi manusia dan mekanisme penyakit. Penerjemah: Adrianto, P. Jakarta: EGC; 1995.

16.Roberts LJ, Morrow JD. Analgesic-antipyretic and anti-inflammatory agents and drugs employed in the treatment of gout. In: Hardman JG, Limbird LE, Gilman AG, editors. Goodman and Gilman's the pharmacological basis of therapeutics. 10th ed. New York: McGraw-Hill; 2001.p. 705

17.Wilmana PF, Gan S. Analgesik-antipiretik analgesik antiinflamasi non steroid dan obat gangguan sendi lainnya. Dalam Gunawan SG, editor. Farmakologi dan Terapi. Edisi 5. Jakarta: Gaya Baru; 2007 